University of Rhode Island

DigitalCommons@URI

Open Access Master's Theses

2017

\title{
Virginia Woolf's Pedagogical Art
}

William R. Bowden

University of Rhode Island, billb75@my.uri.edu

Follow this and additional works at: https://digitalcommons.uri.edu/theses

\section{Recommended Citation}

Bowden, William R., "Virginia Woolf's Pedagogical Art" (2017). Open Access Master's Theses. Paper 1009. https://digitalcommons.uri.edu/theses/1009

This Thesis is brought to you for free and open access by DigitalCommons@URI. It has been accepted for inclusion in Open Access Master's Theses by an authorized administrator of DigitalCommons@URI. For more information, please contact digitalcommons-group@uri.edu. 


\section{VIRGINA WOOLF'S PEDAGOGICAL ART}

BY

WILLIAM R. BOWDEN

A THESIS SUBMITTED IN PARTIAL FULFILLMENT OF THE

REQUIREMENTS FOR THE DEGREE OF

MASTER OF ARTS

IN

ENGLISH

UNIVERSITY OF RHODE ISLAND

2017 


\section{MASTER OF ARTS THESIS}

OF

WILLIAM R. BOWDEN

\section{APPROVED:}

Thesis Committee:

Major Professor Stephen M. Barber

Valerie Karno

Paul Bueno De Mesquita

Nasser H. Zawia DEAN OF THE GRADUATE SCHOOL

\section{UNIVERSITY OF RHODE ISLAND}

2017 


\begin{abstract}
Virginia Woolf (1882-1941) wrote novels and essays with a sense of urgency. During the interwar years 1918-39, Woolf was interested in how public institutions could contribute to war. One institution that she believed contributed rather than prevented England's involvement in the war was the elite education system, which guaranteed young men of the "educated class" learning opportunities and economic advantages.

Though Woolf was herself a member of the "educated class" as a woman she did not have the same rights to an education as the men belonging to the same class. Woolf critiqued both the institution of education as a place dedicated to privileged men, separating outsiders on the basis of gender and class and the coercive lecturing model used to persuade young men to believe that war was a viable option. Through her art, Woolf imagined an alternative pedagogy where men and women could learn collectively.

It is this discussion over the private and public life of English individuals throughout the interwar years that led me to consider Virginia Woolf's work in the context of education. I created a model for contemporary reader/educators who can use the practices outlined in Woolf's work as a framework for developing their own transformative pedagogy.
\end{abstract}




\section{ACKNOWLEDGMENTS}

I thank Dr. Stephen Barber for his enthusiasm and courage. His expertise, passion, and dedication to teaching Virginia Woolf's work encouraged me to take on this project. Rather than letting tasks and important deadlines prevent him from taking time out of his day with me, Professor Barber made it a priority to unpack the work we pursued here. As a role model and a great example of an active scholar, Professor Barber's thoughts, words, and activism are heavily present in this text.

I thank Dr. Valerie Karno for her commitment to this thesis. Her expertise and commitment to new forms of pedagogy inspired much of my work here. Moving forward, I will incorporate her work in digital literacy in future classrooms.

I thank Dr. Paul Bueno De Mesquita for always being an intellectual role model. Professor Bueno De Mesquita's role as an activist for peace and non violence has inspired me since we met when I was an undergraduate. Much of this thesis is informed by what he and his wife taught me in a course on Kingian non violence. Dr. Bueno De Mesquita devotes large portions of his time to thinking about pedagogy. As someone who is interested in alternative pedagogy, I have followed his teaching practices and admired the dialogue that is always present when he teaches. My writing reflects the desire to both write and teach in this way, and this will be a goal that I will maintain for a lifetime.

I would like to thank my parents who made it possible for me to pursue this level of education. From the time that I was five years old and my parents exposed me to texts from the $19^{\text {th }}$ century, I fell in love with the practice of reading. Their time, their commitment, and their hard work made it possible for me to pursue my dreams. My fiancée Rachel Smith has been my anchor throughout the process. Helping me with 
deadlines, finding the right forms to submit and taking care of my time management. This project wouldn't have been possible without her enduring love. I would like to thank Michelle Caraccia, our department's Graduate Program Administrator. There aren't enough words for Michelle who is so passionate about helping students excel. Michelle cannot be thanked enough for making the process seem effortless. Lastly, I want to acknowledge my Nana who will always be my greatest motivator and inspiration, this thesis is dedicated to her. 


\section{TABLE OF CONTENTS}

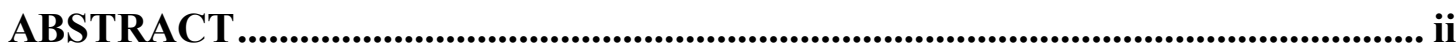

ACKNOWLEDGMENTS ............................................................................................... iii

TABLE OF CONTENTS ...................................................................................v

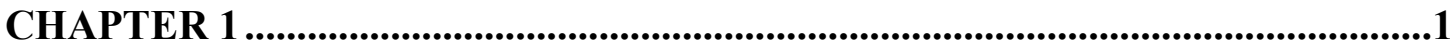

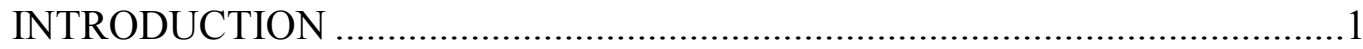

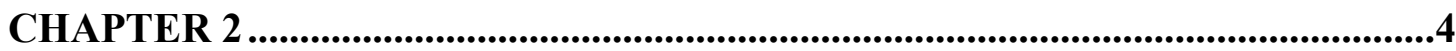

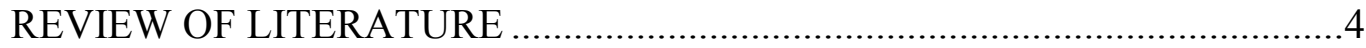

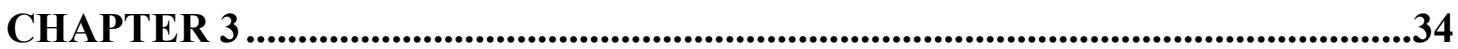

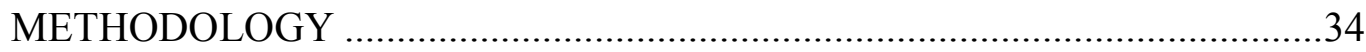

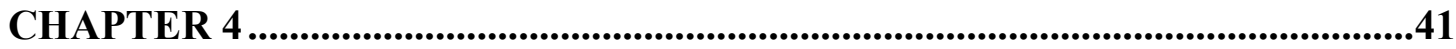

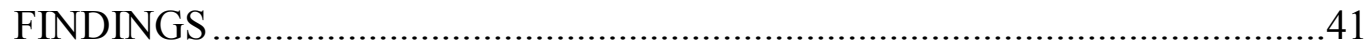

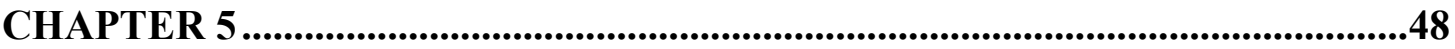

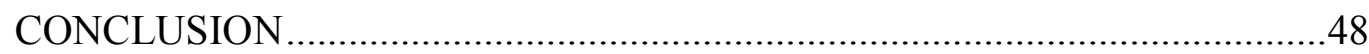

BIBLIOGRAPHY ............................................................................................................50 


\section{CHAPTER 1}

\section{INTRODUCTION}

"Virginia Woolf's Pedagogic Art" is a response to a growing body of research on using literature to enhance learning communities for contemporary educators. Though there is not an abundance of research on reading communities as professional development for teachers, I argue that reading Virginia Woolf's late work can be especially instructive for contemporary teachers interested in using their own reflections as readers to inform their teaching practices.

One example of a professional reading community is Shari M. Goldberg and Ellen Pesko's study in 2000. These two author/researchers formed a book club among a group of high school English teachers. This group would meet, select several texts to read throughout the academic year, and share their thoughts about the books. They read across genres, including both fiction and nonfiction (40). These teachers found it appropriate to reflect upon the way that they read texts and incorporate their own reflection in their classrooms. What they read, and the methods they used while reading (highlighting, sticky notes, journaling) informed decisions they made when they returned to their classroom.

In response to a growing demand for the standardization of reading practices in American schools due to legislation on education, this book club sought to find ways of making reading exciting and provocative for their students. Reading practices came under close examination when President George W. Bush signed the No Child Left Behind Act 
(NCLB) in 2002. Changing perspectives on education and literacy created a need for teachers to think differently about their practice. In 2001-05, "not long after NCLB legislation, literacy coaches and specialists were installed in 5,600 public elementary schools across the country because of Reading First Grants provided to major urban districts such as Chicago, New York, Los Angeles, and San Diego" (Thompson 38-9). Interestingly enough, similar questions provoked intellectuals to think about the role of reading in British culture during Woolf's lifetime (1912-1941). Several of her essays and novels treat education thematically, and Woolf offers a model for reading practices as well. Possessing a severe distaste for the lecturing model of teaching available to Woolf and her contemporaries, she stopped lecturing and began incorporating her ideas on education into the content and style of her writing.

Woolf's informal essay was a vehicle through which she could convey some of her most important and innovative ideas on education (Cuddy-Keane 2). It is important to consider how Woolf would not have used the word pedagogy. Much of this thesis will build upon the work of Melba Cuddy-Keane's Virginia Woolf, The Intellectual, and the Public Sphere (2003). My work will define pedagogy first before it takes a pedagogical Woolf as its subject. As Keane so clearly states, Woolf sought an alternative form of teaching, one that dismissed and overcame the lecturing model most commonly practiced at elite universities during her lifetime (2). For Woolf, thinking was essential, but she wanted to find a way to make the exchange of thought less coercive. The universities, in the 20s and 30s reinforced notions of patriarchy, nationalism, and privilege, which Woolf attempts to dismantle in her polemic, Three Guineas (1938). 
Reading the complex layers of Woolf's ideas on pedagogy in her essays and fiction is challenging and provocative. I believe that if educators are going to be allocated time for professional development to discuss literature, they would do well to begin by incorporating Woolf's work into their reading. Her work offers a picture of education as an institution, education as teaching practice, and alternative spaces where common readers can learn independently. Her objective was to encourage readers to come to their own conclusions without the force of the university specialist.

Contemporary teachers who interact with texts for the sake of improving their teaching practices might read Woolf's work as a tool for increasing both their students and their own autonomy. I encourage teachers to read more than Woolf's texts alone, but since Woolf writes fiction as well as essays that are intensely interested in education, I believe that it is a viable starting point. This thesis will offer a guideline for English teachers who are interested in incorporating literature into professional development. It will also offer a picture of the transformation of the English term pedagogy from the $15^{\text {th }}$ century to the present date, considering its redefinition and reapplication in the twentyfirst century. 


\section{CHAPTER 2}

\section{REVIEW OF LITERATURE: DEFINING PEDAGOGY THEN AND NOW}

Contemporary teachers who interact with texts for the sake of improving their teaching practices might read Woolf's work as a tool for increasing both their students and their own autonomy. I encourage teachers to read more than Woolf's texts alone, but since Woolf writes fiction as well as essays that are intensely interested in education, I believe that it is a viable starting point. This thesis will offer a guideline for English teachers who are interested in incorporating literature into professional development. It will also offer a picture of the transformation of the English term pedagogy from the $15^{\text {th }}$ century to the present date, considering its redefinition and reapplication in the twenty-first century.Pedagogy came into common use during the $15^{\text {th }}$ century. Until the $17^{\text {th }}$ century, pedagogy was still being used in English to describe the location where individuals were

educated. By the late $20^{\text {th }}$ century into the present day, pedagogy was redefined. The most general understanding of pedagogy now is teaching practices informed by theory (OED 2016). It is important to understand the etymology of the word at the outset of this project. Melba-Cuddy Keane (2003) takes the "pedagogical Woolf” as her subject, but does not express concern over the fact that Woolf and her contemporaries would not have used this word. It is fascinating that although Woolf wouldn't have been familiar even with the $15^{\text {th }}$ century definition, her work could still be read as pedagogical in the $21^{\text {st }}$. There is, I agree, something in Woolf's art that is instructive, as English readers might understand "pedagogy" today. However, I also think that she complicates the archaic 
understanding of pedagogy as well. She does this by seriously challenging the grandeur of the space allocated to elite universities during her lifetime. Woolf sought to undo the "fetish" of elite education for young men in the 1920s and 30s in Britain. One of her methods was to determine how the immense sum contributed to universities to improve the appearance and ceremonies within the boundaries of the school was problematic. When Woolf reimagines alternative spaces for education; she pictures public spaces that bear no resemblance with the elite schools, namely Oxford and Cambridge. Woolf points to the public library as a democratic space that is free and available to everyone across class and gender.

While Woolf deconstructs the physical space of the elite university and reconstructs spaces that are available to wider groups of individuals, she also writes in a way that openly engages with readers. Her relationship with readers is based on dialogue rather than a monologue, the latter was the most common style of teaching adopted by male "specialists" in the British universities at the time. Woolf becomes "pedagogic" for $21^{\text {st }}$ century readers of English who understand her art as a response to increasingly restrictive forms of education. It is important, therefore, to commit to reviewing her work and the secondary scholarship on her work to understand Woolf's relationship with pedagogy. The following questions will inform the literature review: What does it mean to be pedagogical? How does Woolf collapse privileged spaces of education during her lifetime? How is Woolf's writing itself pedagogical? What types of exercises does Woolf offer for educators and students in her late essays and novels? What influence can her work have upon contemporary education? It is with intense attention to this last question that I turn to her thematic treatment of education in her polemic Three Guineas (1938). 


\subsection{WOOLF'S THEMATIC TREATMENT OF EDUCATION IN THREE GUINEAS}

It is clear that Virginia Woolf was closely observant of the institution of education during her lifetime. Both the role of the intellectual and the institution of education were under scrutiny during the 1920 s and 30s when she was composing much of her work. The expansion of adult education to the "masses," namely, working class men and women of all social classes, challenged thinkers during the period to reflect on the ultimate aim of education. Woolf sought to provide members of the working class and women a model for education that would not resemble an elite male education that had been religiously preserved for over 500 years. English families, according to Woolf, had been making contributions to this "voracious receptacle" for centuries. They even sacrificed their daughter's livelihood for the education of young men, contributing any time and money that could be useful for their daughters by focusing on educating their sons in a particular manner. This created enormous disparities that troubled Woolf who then used the informal essay as a genre to expand upon the vestige of education.

Woolf's art is pedagogic in the sense that it invites readers to contemplate relevant questions and work with the author to achieve their own independent conclusions. This directly opposes the lecturing model available to teachers during the early twentieth century, which was becoming increasingly objective and specialist. Lecturing often involved the imposition of thoughts from an authority figure onto their students. Woolf juxtaposed lecturing with the type of education that allows individuals to form their own opinions. She juxtaposes the public library with the university as a space where common readers could ponder thoughts freely, and she offered self-reflexive reading practices as 
an exit from the constraints of the coercive educational system. When Woolf was working to undo the exclusive system of education, I don't think that she only had women and working class individuals in mind. I also think that Woolf was trying to reach an elite male audience. Although not explicitly stated by Woolf, I argue that Woolf wanted to find ways to uncoercively rearrange the desire (to paraphrase Gayatri Chakravorty Spivak) of young British men and women during a time when professional life and education were slowly becoming available for women and members of the working class (Spivak 81).

Her effort involved encouraging what she called common readers to find opportunities to learn through public venues such as the library when they had been denied access to elite universities because of their social class. She also wanted to undo the privileged learning of men who were often inspired to leave home for war because of the nationalist rhetoric reinforced at the university, even by professors of literature (30). Woolf believed that these men had a different understanding of England because they saw it from a different angle. Their vision of England for Woolf was informed by the privilege they "sat" upon because of their upbringing and education. Access to a formal institution, travel, rare texts, and sport, changed the way that privileged men thought and interacted with the world ("The Leaning Tower, 265; hereafter cited as "LT").

To have a thematic understanding of Woolf's purview regarding the exclusionary practices of the elite university during the 1930 s, one must turn to her polemic Three Guineas (1938). Three Guineas offers a snapshot of privileged education both on the surface and in depth, with the purpose of undoing practices, celebrations, and the lack of criticism surrounding elite or what would then be called 'highbrow' procedures. Woolf's 
argument in response to an interlocutor who poses the question, "How in your opinion are we to prevent war?" is to consider the implications of an education that fosters competition, patriarchy, nationalism, and excludes most members of society and therefore reinforces notions of dominance. Internal conflict influenced broader conflict across the world (TG 3). This seems to be partially why she places so much emphasis on the infamy of privileged universities during the time, and the harm that they caused the general public. Woolf believed that education reserved for men of the upper class during this time literally changed the landscape of England (" $L T$ " 265 ). The problem was, It was a voracious receptacle, a solid fact—Arthur's Education Fund — a fact so solid indeed that it cast a shadow over the entire landscape. And the result is that though we look at the same things, we see them differently. (TG 5)

She offered a deluge of information about elite universities. Rather than simply creating a polemic based on little or no data, her writing is supported by a foundation of research suggesting an upheaval of bequests created an elite system, which incurred greater distances between educated "highbrows" and the "masses." One example of tangible information that she uses to make her argument is the income of Oxford and Cambridge universities in the 1930s. She records,

The income of Oxford University is $£ 435,656$ (1933-4), the income of Cambridge University is $£ 212,000$ (1930). In addition to the university income each college has its own separate income, which, judging only from the gifts and bequests announced from time to time in the newspapers, must in some cases be of fabulous proportions. (TG 26) 
These generous donations of wealth to universities for young male students would have allowed them to travel, to have access to private texts restricted to individuals outside of the university, and almost always guaranteed that these men would leave school with opportunities for well compensated employment. On the other hand, members of the working class and women had no access to these privileges and therefore, Woolf believed that though they would be living in the same environment, they would describe and consider events, texts, and art differently. The desire for education wasn't exclusively characteristic of wealthy men. Woolf uses textual evidence, especially biography to show that women and members of the working class desired the same opportunities to learn. Woolf's text then, works against normative elite education in order to suggest that when women and working class individuals are granted access to education, their education should not resemble that of the privileged male. This is something that she will continue to reiterate not only throughout Three Guineas but several of her other texts. Woolf has a strong belief that it is the institution of education that corrupts, and that if education should be founded for women and working class citizens, it should be fostered on poverty and a love for learning,

And so with the other arts and artists. They would come to the poor college and practice their arts there because it would be a place where society was free; not parceled out into the miserable distinctions of rich and poor, of clever and stupid; but where all the different degrees of mind, body, and soul merit co-operated. Let us then found this new college; this poor college; in which learning is sought for itself; where advertisement is abolished; and there are no degrees and lectures are not given, and sermons are not preached. (TG 33) 
The elite educational system relies heavily on convention and traditions while Woolf's vision for alternative pedagogy would focus on the here and now, connecting reality with thought, disciplined reading with an attention towards social justice. By opening the mind, the common reader has access to epistemological rewiring, which members of the elite classes would not have had because they were indoctrinated by a habitus. Learning outside of Oxford and Cambridge, to use examples, would enable common readers to achieve a type of freedom denied to members of the privileged community who were "locked in." Woolf would discuss this theme further in her 1940essay "The Leaning Tower," which she presented to a group of working class men. She distinguishes between "outsiders" and a class of privileged men educated at the university who sit upon a tower of privilege afforded by their education. One example of a male contemporary who was "locked in" by the coercive ideology of the established education system was Desmond McCarthy. McCarthy reviewed Woolf”s “The Leaning Tower" which was originally presented as a talk given to members of the Worker's Educational Association. McCarthy's critique of Woolf was that as a member of the so-called educated class, she shouldn't use the pronoun 'we' when she addressed men and women of the working class. What McCarthy didn't take into consideration was that Woolf never earned a degree as a woman. She was more closely aligned with members of the working class than he in this regard. As Cuddy-Keane relates, Woolf's 'we' was an attempt at a collective democratic project (111). When Woolf wrote back to McCarthy she acknowledged the gulf between herself and the working class while she also points out that because McCarthy was guaranteed a privileged education she was "about four thousand five hundred and fifty pounds nearer them than you are" (L VI: 468). 
Though these men, her contemporaries, begin to notice how their privilege separates them from the rest of human life and begin to critique the system that has allowed them to have monetary advantages in life, they cannot come down from this tower. They cannot dissociate themselves from the privilege they have already received. Since they have already been on the other side of privilege and participated in this tradition, they are unfortunately unable to simply deny the vehicle through which they have become successful, employed, and wealthy. Members of the working class and women, on the other hand, who never had the same access to formal education, can reflect upon the impact this "tower" has had upon British society, but they are permitted, as Woolf relates, to come back down from this tower. It is an interesting time for reflection. On the precipice of some collapse in the complete privilege of males who have access to the private sector of professional life, women, and working class individuals began to have access to these spheres.

Woolf, ahead of her time, makes every effort to think about how together outsiders can best take advantage of these new privileges without destroying themselves in the process. She recognizes the tendency in elite males who have already gone through this process of coercion to forget about the axiom of privilege and to ignore the type of ignorance that privilege can induce. Woolf does not see women and working class people as impossibly out of the reach of this indoctrination. She carefully offers a model, which would enable them to become more self-reflexive as they begin their journey into the private sphere of education and professional life. It is this challenge that inspires her to write: 
Think we must. Let us think in offices; in omnibuses; while we are standing in the crowd watching Coronations and Lord Mayor's shows; let us think as we pass the Cenotaph... let us think at baptisms and marriages and funerals. Let us never cease from thinking — what is this civilization in which we find ourselves? What are these ceremonies and why should we take part in them? What are these professions and why should we make money out of them? Where in short is it leading us, the procession of the sons of educated men? (TG 60)

The closest contemporary word to describe Woolf' reflection on thought would be metacognition. Metacognition has appeared most frequently in education scholarship within the past decade. The word describes the practice of reflecting on one's own thoughts. When someone reads a book, they might spend a significant time recording in a notebook or computer what they thought about the text. Taking a step further, the reader might think about her own thoughts and the implications of those thoughts.

Metacognition has become a topic of interest for scholars in education who are interested in teachers who reflect upon their thinking processes.

As with "pedagogy," Woolf wouldn't have been familiar with the word metacognition. In the passage above, however, it is clear that she is interested in the process of thinking through everything one encounters. If teachers began to use this type of thinking in their classroom, their lessons might reflect the thoughts and interests of their students. Teachers might also incorporate after generous time devoted to reflection, whatever they discovered in thought would be useful to help students achieve the literacy goals that they were expected to meet. State standards and teacher accountability did not exist during Woolf's lifetime, so the urgency for this type of thinking in schools wouldn't have been 
as immediate, but metacognition as an accomplishment for British citizens to aspire to was important for Woolf especially during the interwar years. Since she saw education for elite men as part of the system of war making, this was more of an urgent concern and reflecting on one's own thoughts would have served the purpose of forming a stronger citizenship, one that was pedagogically transformed and that could make better ethical decisions that would not lead to war. 


\subsection{PEDAGOGY AS PLACE: UNIVERSITY OR PUBLIC LIBRARY?}

Woolf does not refer to the word "pedagogy" in her novels and essays. It is interesting that her writing nevertheless reflects both the original definition and our contemporary definition of the word. Woolf considers the former meaning of pedagogy quite seriously in her work. In the $15^{\text {th }}$ century as stated earlier, pedagogy was used to describe the place where individuals were educated (OED 2016). Woolf is obsessed with the culture of the existing schools and universities of her lifetime. She studies the structure of elite universities and reflects on different people's understanding of these schools. On the one hand, the university's alumni might feel nostalgic when they pass by their old school, whereas working class men and women who were never admitted might see something completely different

What is that congregation of buildings there, with a semi-monastic look, with chapels and hills and green-playing fields? To you it is your old school, Eton or Harrow; your old university, Oxford or Cambridge; the source of memories and of traditions innumerable. But to us, who see it through the shadow of Arthur's Education Fund, it is a schoolroom table; an omnibus going to class; a little woman with a red nose who is not well educated herself but has an invalid mother to support. (5)

We can imagine that Woolf is trying to show how individuals who attended these schools would have a different perspective on the places where they learned (nostalgia, pride) but also a different outlook on life: literature, politics, and events because of the place where they acquired an education. Since they received a formal education and were 
taught how to think, it follows that they would perceive external events, texts, and objects differently.

This is part of the reason why the narrator writes to her first interlocutor in Three Guineas, "It is now that the first difficulty of communication between us appears" (4). If students of the university had a certain perspective because of the way that they had been taught to think, then working class men and women who weren't students at these schools must think differently. Although they see the same things, they think about them differently. Woolf would dwell heavily upon interpretation as a critical practice for "common readers." Instead of duplicating the existing universities both in appearance and practice, she suggests that alternative schools [m]ust be built not of carved stone and stained glass, but of some cheap, easily combustible material which does not hoard dust and perpetrate traditions. Do not have chapels. Do not have museums and libraries with chained books and first editions under glass cases. Let the pictures and books be new and always changing. Let it be decorated afresh by each generation with their own hands cheaply. The work of the living is cheap; often they will give it for the sake of being allowed to do it. (133)

Woolf imagines the public library as an especially viable space for the free acquisition of knowledge by men and women of any social class. She juxtaposes the university library in A Room of One's Own (1929) with the public library in "How Should One Read a Book?" (1932) and “The Leaning Tower" (1940). In A Room of One's Own, the narrator stumbles upon a university's grounds. When the narrator reaches the library, 
Instantly there issues, like a guardian angel barring the way with a flutter of black gown instead of white wings, a deprecating, silvery, kindly gentleman who regretted in a low voice as he waved back that ladies are only admitted to the library if accompanied by a Fellow of the College or furnished with a letter of introduction. (8)

Here there is a standard: only some people are not allowed in. The university (including its library) is always represented in Woolf's work as both grandiose and oppressive. She wants to dismantle it completely and hopes to diminish the traditions associated with it in the process

But it is also plain that outsiders who find you thus occupied must ask themselves, when they receive a request for a contribution towards rebuilding your college, shall I send it or shan't I? If I send it, what shall I ask them do with it? Shall I ask them to rebuild the college on the old lines? Or shall I ask them to rebuild it but differently? Or shall I ask them to buy rags and petrol and Bryant \& May matches and burn the college to the ground? (TG 32)

Rebuilding the university would involve taking a risk.

As an alternative model readers can come to their own conclusions when they visit the public library. In this space, education completely changes. There is no money involved, no privilege; only the desire to learn for the pleasure one can derive from it. Woolf does not create a character who blocks potential readers from the doorway; instead, she makes clear that the library will be a place for radical democracy:

To admit authorities, however heavily furred and gowned, into our libraries and let them tell us how to read, what to read, what value to place upon what we read, 
is to destroy the spirit of freedom which is the breath of those sanctuaries.

Everywhere else we may be bound by laws and conventions - there we have none. (258)

Freedom as opposed to rote teaching and learning is the property of the public library. Space is therefore an important part of Woolf's theses on education reform.

Coincidentally, pedagogy was originally defined as the location where individuals were educated. Woolf pays careful attention to how learning environment influence students. She also considers pedagogy, as English readers understand it today, teaching practices informed by theory. 


\subsection{PEDAGOGY AS TEACHING PRACTICE}

Beginning in the early twentieth century, alternative schools were created for working class men and women. The classes met at night and were often taught by members of the upper middle class (both men and women) who had been taught at elite universities such as Oxford and Cambridge. E.M. Foster was one example. He began teaching weekly classes in Latin in 1902 (Cuddy-Keane 82). Woolf began shortly after in 1905 at Morley College where she taught history, literature, and composition until 1907. Though her teaching experience was ephemeral, it ended up informing her writing for the rest of her lifetime (84). The working-class colleges encouraged teachers to increase student autonomy and interaction with their instructor. Rather than reading her written lecture directly, Woolf read from her notes allowing her to engage in more conversation with her students (83). She also began using pictures and narratives to bring English history alive and we remember her use of photographs in Three Guineas, among other texts to help readers understand hidden issues that required the uncovering of multiple layers of discourse and perception. The reason that Woolf wanted to change the way she lectured was because she struggled with "the fundamental difficulty of bridging the gap between her students' lives and her historical materials" (83). The underlying challenge for Woolf was the distance between the student and herself in terms of class. Many teachers who taught at Morley College, the Working Men's College, and King's College, London, came from a different background than their students. Woolf thought about this relationship any time she wrote about education. On the one hand she wanted to collapse the distinction between teacher and student in the elite universities, but on the other hand she didn't want so much to collapse this distinction while she taught at Morley instead 
she wanted to acknowledge that difference. She discusses this problem in her essay "The Leaning Tower," where privileged men sit upon a chair elevating them above the rest of society. By the time she reaches her male contemporaries in that essay, these men wish to become closer to the rest of society. They use their sympathies with others as a scapegoat but they do not acknowledge that they came from a position of extreme privilege.

Although Woolf had the chance to take some private classes while most women still did not have access to public education, she never earned a degree and this would separate her even further from the male contemporaries of the "educated class" who were mostly graduates of Oxford and Cambridge. Despite not receiving a formal education, Woolf is still attentive to the differences between her students and her own upbringing. This realization on her part seems to inform much of her teaching:

Woolf's difficulties reflect one of the basic problems in adult education of the time: despite the fine ideals of fellowship, the education was situated in the discourse of the educated upper middle class, reinforcing inequalities between teacher and student and placing the materials of study in a realm above and beyond the student's world. (Cuddy-Keane 83)

This seems to be why Woolf rails against lecturing throughout her life. In Three Guineas she reinforces this idea: "If we are asked to lecture we can refuse to bolster up the vain and vicious system of lecturing by refusing to lecture" (TG 35). Lecturing wasn't the appropriate medium for Woolf; she didn't believe that it would help the teacher reach students and actually help the latter think independently. It exasperated her that Walter Raleigh, professor of English Studies at Oxford, was considered successful as a teacher. She believed that Raleigh reinforced notions of patriarchy, militarism, and egotism in 
both his writing and lectures. In her essay, "A Professor of Life" (1926), she writes "people who heard him said that his lectures stimulated them, opened their eyes, made them think for themselves" (342). Independent thinking was something that Woolf wanted to encourage readers to do, but she couldn’t fathom how Raleigh would have achieved this objective. Cuddy-Keane suggests that Woolf's genial writing style could have made readers take her ideas less seriously because they didn't believe what she was writing was meant to be instructive. She often layered texts and meaning and despite some rather aggressive words for the elite system of education in Three Guineas, Woolf maintained a dialogic model of writing and teaching rather than a "coercive and combative" style (95).

Establishing a balance somewhere between being an authority or a partner in dialogue is still an issue for educators today. Christopher Emdin explores these types of questions in his work, when he considers how teachers can collapse standardized models of teaching and recreate lesson plans that find students where they are and educate them on the basis of culture, interests, and prior knowledge (2014). Emdin inspired educators to think about creating opportunities for students to have a voice in their education. I think that Woolf had something similar in mind when she wrote texts on education and actually taught at Morley. Though critical pedagogy wouldn't have been available to her as a concept or practice, Woolf came close to the practitioners who follow that model of teaching practice today.

Although women were first permitted to take examinations at Cambridge University in 1882, they could not earn a degree until 1921. When Woolf wrote Three Guineas between 1934 and 1938, education for women and working class men began to 
bloom. Women were beginning to have more opportunities to earn their own living rather than be dependent upon their fathers and brothers who had been permitted to do so already. Before women are completely immersed in public life as professionals and students, Woolf cautions them to think about the implications of this precipice on which they stood. How would they do things differently in order to avoid perpetuating war and the fragmented class system?

We are here, on the bridge, to ask ourselves certain questions. And they are very important questions; and we have very little time in which to answer them. The questions that we have to ask and to answer about that procession during this moment of transition are so important that they may well change the lives of all men and women for ever. For we have to ask ourselves, here and now, do we wish to join that procession or don't we. (59)

Always leading with questions, not determinations, Woolf wonders what the next step will be. Instead of letting this moment go, only thinking about these questions for a second and passing on, she suggests that these questions need immediate answers. The urgency of change is influenced by the presence of war in Europe. The Second World War would begin the following year (1939) and eventually England would experience attacks right at home. This contributes to Woolf's essay "Thoughts on Peace in an Air Raid," (1940) which is beyond the scope of this study, but it is interesting that there she sees education as intermingling with the threat of war. If teaching practices used in the elite universities were reinforced in working class colleges and professions, then Woolf's fears would come true. The only way out of the conditions that create war, for Woolf, is through constant reflection, 
Think we must. Let us think in offices; in omnibuses; while we are standing in the crowd watching Coronations and Lord Mayor's shows; let us think as we pass the Cenotaph... let us think at baptisms and marriages and funerals... Let us never cease from thinking — what is this civilization in which we find ourselves? What are these ceremonies and why should we take part in them? What are these professions and why should we make money out of them? Where in short is it leading us, the procession of the sons of educated men? (60)

Woolf's answer would be that it is leading them to war. She does advocate for an alternative though. In "Thoughts on Peace in an Air Raid" Woolf records, writes, "Thinking is my fighting." Her pacifism informs her teaching practice. Gayatri Chakravorty Spivak's work in the twenty-first century resembles Woolf's teaching practices. Spivak suggests that humanities education should be the "uncoercive rearrangement of desire" (81). During a time of confusion and anxiety about the potential for war, Woolf explores what it means essentially to uncoercively rearrange the desire of English citizens. In "How Should One Read a Book," she begins, In the first place, I want to emphasise the note of interrogation at the end of my title. Even if I could answer the question for myself, the answer would apply only to me and not to you. The only advice, is to follow your own instincts, to pursue your own reason, to come to your own conclusions. If this is agreed between us, then I feel at liberty to put forward a few ideas and suggestions because you will not allow them to fetter that independence which is the most important quality that a reader can possess. (258) 
Once again occupying the role of writer/teacher Woolf recommends that her readers form their own conclusions. Writers should not be authority figures; for her, they should be partners in thought. This was the major difference between the teaching styles at elite universities and subsequent universities developed for members of the working class. The former emphasized methodological practices that Woolf believed were mechanical, while the latter placed an emphasis on dialogue in the classroom. Woolf did not achieve all of this within the classroom though. As mentioned earlier, she only taught for two years. Instead, she found more opportunities to express her concerns in her essays and novels because

Writing... did not require the same institutional sanction as lecturing, and writing was more conducive to her complex dialogic approach. At a time when public concern had highlighted the need for adult education and attention to reading, Woolf conceived a non-institutionalized, alternative pedagogy. The informal essay or review, published through a private press, and made available through free libraries, was her way of taking pedagogy to the street. (108)

There were some limitations to her speaking and lecturing. Cuddy-Keane points out that Woolf tried to dismantle the lecturer's assumed authority when she spoke with the Worker's Education Association (WEA) but "her scattered self-qualifiers did not sufficiently encourage her audience to speak" (107). It is clear that for Woolf teaching requires constant attention and what we might call in the twenty-first century professional development. The teacher as well as the writer must engage in metacognition, reflecting upon what one thinks, because if they do not they risk taking the role of an assumed authority denying reader/students freedom to develop their own thoughts. 


\subsection{READING LITERATURE FOR PROFESSIONAL DEVELOPMENT}

Melba Cuddy Keane writes, "Virginia Woolf was an intellectual writing at a time of public debate about the role of intellectuals and the nature and value of literary education" (I). The concern over how and why literature is taught did not come to an end in the early $20^{\text {th }}$ century when Woolf composed her work. In fact, since the early 2000 s, educators in America have become increasingly attentive to the way literature and reading practices are taught (Morrell 2014). As the result of the No Child Left Behind Act signed by President George W. Bush in 2002, and the Common Core State Standards coordinated by state schools chiefs and governors in 2009 , teachers and administrators have been held accountable for their students reading comprehension, which is often measured in the form of standardized test scores.

Since the Common Core was introduced, teachers have been required to think about how the texts they present to students in the classroom will help them meet the objectives proposed by the state. States have been allocated money from the federal government because of their performance on standardized tests. The question for teachers has been how to allow students autonomy in the classroom while also attempting to meet specific goals. One practice that has been empirically proven as an aid to teachers is professional development that encourages teachers to participate in learning communities with colleagues and students who can inform the teacher's perspective on how and why they should teach reading (Thompson 2014). Reading specialists and curriculum development experts have created new methods for teachers to reflect on their own reading and teaching practices. 
Inspired by Oprah Winfrey's idea of a national book club, researchers Shari M. Goldberg and Ellen Pesko mailed flyers to teachers introducing the idea of a voluntary and free book club for local teachers to come together and select texts to read and discuss. Their objective was to create opportunities for teachers to revisit and be cognizant of their own reading practices. This allows, according to their research, teachers to notice the limitations as well as the empowering aspects of their existing teaching practices (40). Goldberg and Pesko write,

While Teacher Book Club members read, they reflected on their process and their needs as readers. They found that having uninterrupted blocks of time for reading, journaling, and discussing had a positive impact on their attitudes. Teachers used comprehension strategies that required interacting directly with the text, such as highlighting and using sticky notes to mark important passages, which lead them to consider suggesting the techniques to their students. (40)

The book club functions as a model of trial and error which allows teachers as readers to reflect on their own practices and shortcomings in order to discover new methods for reaching their students. The members of the club read across genres, discussing which topics and novels will be teachable (40). Instead of attending a conference, for example, teachers might spend time in smaller focus groups allowing them to engage more specifically with their own practices and create new lesson plans with other teachers who have experience in the field. Or, teachers who have limited amounts of experience can benefit from spending generous amounts of time with veteran teachers. One member reflects, 
It's interesting that when we talk about ourselves as readers, a lot of the things I do and have done in the past to kids are things that I don't like to do. Teachers feel an obligation to expose things to kids year after year... genre wheels, 25 million comprehension questions, and worksheets. We have a lot of kids who don't like to read, and I wonder if it's to do with all the teacher directed control.

Incorporating reading for pleasure, something Woolf advocates for incessantly during her lifetime, teaches educators how their students might want to read. By reflecting on this in groups, teachers can make reading practices more enjoyable for youth. The book club encourages teachers to model collaborative reading methods in their classroom and create lessons allowing students to engage in similar types of reflection. Some of the questions that members of the book club found important for students and teachers to ask are, What do they do when they are puzzled about the meaning of a text or when they simply find it hard to get into the book? What do they find that they wish to share; and what techniques work for keeping track of their thoughts and feelings about what they read? A club offers opportunities to connect personal knowledge about literature with pedagogical knowledge for teaching literature. (39-40)

These questions and conversations, Goldberg and Pesko hope, will inspire more teachers to engage in what they call "reauthentication." Moving away from a model of education where educators disinterestedly pass out worksheets reinforcing a rote dynamic in the classroom. Reading literature for professional development reacquaints teachers with the material they fell in love with in the first place. The purpose of the book club, the authors argue, is to allow teachers to "tap into their love of reading while developing new 
understanding of their students needs" (39). Goldberg and Pesko are not the only educators who see the value in reading communities for teachers.

Kierstin H. Thompson makes a similar argument in "Beyond the Stacks: Why High School English Teachers Should be Talking About Books." Inspired by conversations with 13 educators in Midwestern high schools, Thompson's purpose is to show how education policy in the last two decades has influenced classroom discussions about literature. Citing anecdotes from conversations with English teachers, Thompson also discusses the complex practices teachers and students have to navigate in order to meet mandated standards. Lastly, Thompson makes an argument for critical conversations among educators about the literature they read, how they read it, and how literature can become a vehicle through which they achieve their pedagogical goals. The link between Goldberg and Pesko's article and Thompson's work is a popular focus word in research on teaching practices during the $21^{\text {st }}$ century: metacognition. Metacognition has been defined in the Oxford English dictionary as "Awareness and understanding of one's own thought process, esp. regarded as having a role in directing those processes" (OED 2016). Metacognition, these authors assert, is an important part of professional development for English teachers (39). Thompson argues,

The fact that high school English teachers consider a variety of factors such as genre, literary era, student interest, student ability, aesthetic value, and point of view as part of their evaluation indicates that they have a lot to say about how they read and frame learning in their ELA classrooms. (39)

One limitation that Thompson believes depreciates the value of metacognitive practices is the lack of opportunities English teachers have to meet and discuss the "content of their 
instruction" (41). In "The Teacher Book Club" Goldberg and Pesko note that it is important for teachers to have time, space, and materials for reading and conversation. The school district where the teachers met for this book club provided the meeting place and the books. While most districts will allocate time for teachers to attend conferences, these authors note that not every conference will be relevant and productive for the specific needs of the audience. Though conferences can be useful for teachers, they are often large and generalized, whereas small group discussions for teachers who have experience in similar teaching environments provides more room for dialogue and application between professional development and actual teaching practices. For my purpose here, I think it is useful to pay close attention to Thompson's suggestion,

To promote such pedagogical and literary consciousness it's crucial that English teachers with diverse backgrounds, beliefs, and experience levels engage in professional development opportunities that go beyond reading strategies or text exemplars (42).

Both articles suggest modes of reading literature that might be useful for professional development, fiction as well as nonfiction. Typically, teachers will read for practical purposes only (Goldberg \& Pesko 39). They might read

Children's literature to choose appropriate books for their students, and they read the student textbooks and teachers' manuals that they use in the classroom. They also read professional literature books and journals that enhance their practice.

Goldberg and Pesko suggest that interaction with texts for the sake of utility alone are often reductive. They take away from the amount of reflection a teacher commits to and 
the result of that is the teacher having less to take away and apply in the classroom. They recommend that teachers incorporate reading for pleasure in order to increase the amount of reading and reflection they themselves engage in during the academic year.

Encouraging teachers to read challenging texts collectively, this research argues, allows teachers to have a closer experience with their students. By taking notes and actively participating in conversation with colleagues, teachers have experience with critical practices that they can then go through step by step with their students. They might also create these collaborative reading environments within their classroom (40). Thompson creates a framework for educators interested in this type of professional development: (I) reading a text that stretches you as a reader; (II) invite colleagues to read a book with you; (III) ask to pilot a text; and (IV) propose a professional development opportunity focused on literature (43). The purpose of this scholarship is to point out the value in educators reading literature in collective groups, engaging in metacognition, taking their shared experience in professional development and using this experience to inform their pedagogical practices. 


\subsection{SCENES OF READING}

An important method for teaching literature and reflecting on teaching practices is through the analysis of scenes of reading. Scenes of reading are instructive moments when a reader encounters characters who are reading in a novel, causing the reader to reflect upon how she is herself interpreting the text at hand. These scenes can also occur, according to Susan Friedman, when a teacher pays close attention to the ways their students read (101). Friedman interprets the ways in which her students read Woolf's work, which informs both the ways she teaches the material and writes about it in her own scholarship,

You know the scene, the scene of your students reading Woolf. If you are not (yet) teachers, you can imagine it, you can recreate the scene of your own first reading of Woolf. At least for those of us far from the scenes of elite education, there is (at first) the confusion, bewilderment in their (our) eyes the sense of reading on quicksand, the fear of speaking uncertainly, the resistance to uncovering battlement - the resistance, period (101).

Exposure to texts usually brings some questions to mind. Not only about the text one is reading, but how one reads and why readers think in certain ways (102). It is interesting to consider how scenes of reading, so important in Woolf's work, can be useful for educators. Friedman believes that,

Each textual disruption of convention invites a matching reading strategy that has pedagogical implications. For how we read affects how we teach our students to read. The text's pedagogical efforts in teaching us how to read it imply a related pedagogy for our teaching it. (103) 
One example of how a novel written by Woolf uncoercively invites readers to read the text is her last novel, Between the Acts published posthumously in 1941. Although it is challenging to determine which scenes are scenes of reading and which are not in this novel, the scope of this literature review will only permit a reading of select pages.

Between The Acts argues that public and private lives are inextricable. One of the ways the novel communicates this message is through scenes of reading. These scenes encourage active rather than passive reading. "Active" might be understood here as reading for depth and meaning rather than understanding texts as they appear on the surface. The novel continues Woolf's critique in Three Guineas that established education leads to war making. In Between the Acts we are taught to build word upon word, carefully interpreting what we are consuming. This is a type of pedagogy that permits us to see a connection between public and private, militarism, and the subjection of women. Isa in Between the Acts reads a story about rape in a newspaper article. She carefully examines the rape through three different modes of interpretation (I) Fantasy, (II) Romance, and (III) Reality:

For her generation the newspaper was a book... She took it and read: 'A Horse with a green tail...' which was fantastic. Next, 'The guard of Whitehall...' which was romantic and then, building word upon word, she read: 'The troopers told her the horse had a green tail; but she found it was just an ordinary horse. And they dragged her up to the barrack room where she was thrown upon a bed. Then one of the troopers removed part of her clothing, and she screamed and hit him about the face.' That was real; so real that on the mahogany door panels she saw the 
arch in Whitehall; through the Arch the barrack room; in the barrack room the bed, and on the bed the girl was screaming and hitting him about the face. (20) Rather than reading the news as factual, Isa reads the story actively and imaginatively. She thinks through the surface of the text and discovers the militarism (the guards who rape the woman and use force) and the private subjection of this woman in a patriarchal culture. One might imagine by reading Isa's reading of the newspaper article that public and private could be linked.

I will provide one further example of how building word upon word enables readers to see what otherwise remains indiscernible in this novel. There is another story about rape that is not presented in the newspaper. This story depicts the subjection of women under a patriarchal culture on a deeply symbolic level. Here, building word upon word, readers follow the novel's figuration of fish. Consider the following passage:

They had first met in Scotland, fishing — she from one rock her from another. Her line had got tangled; she had given over, and had watched him with the stream rushing between his legs, casting — until, like a thick ingot of silver bent in the middle, the salmon leapt, had been caught, and she had loved him. (48)

The institution of normative heterosexuality inscribes women's subjection to men in this book. This becomes all the more resonant in another passage in the novel where we see Lucy Swithin has been raped at the very least symbolically by her brother.

Lucy, his sister was three years younger than he was. The name Cindy, or Sindy, for it could be spelt either way, was short for Lucy. It was by this name that he called her when they were children; when she had trotted after him as he fished, and had made the meadow flowers into tight little bunches, winding one long 
grass stalk round and round and round. Once, she remembered, he had made her take the fish off the hook herself. The blood had shocked her-"Oh!" She had cried — for the gills were full of blood. And he had growled: "Cindy!" The ghost of the morning in the meadow was in her mind... (21)

The novel encourages self-reflexivity. Recognizing as the playwright Miss LaTrobe does toward the end of the novel, "Consider the gun slayers, bomb droppers here or there. They do openly what we do slyly." (187) LaTrobe seeks not only to teach her immediate audience, but the audience that encounters the text (from the outside). Asking readers to consider both alterity and the ways in which private and public life seems inevitable to collide. This is the pedagogic function the novels wishes to serve, causing the audience to become self-reflexive in order to recognize how private and public life appear to influence one another. 


\section{CHAPTER 3}

\section{METHODOLOGICAL PROPOSALS: MEETING WOOLF}

This project was inspired by a seminar that I took during my first year in graduate school. The seminar was on Virginia Woolf and the genre of the novel. I had never read Woolf's work prior to this class; however, by the time I took the course I had already developed an obsessive passion for contemporary and historical teaching practices. During the seminar we read Woolf's late work as well as supplementary scholarship and I realized that her writing had pedagogic tendencies. Woolf offered both a thematic treatment of education in the 1920s and 30s, and her writing style was in fact, pedagogic composition. By “pedagogic composition," I mean to say that she intended to find alternative modes of pedagogy through and by her writing. This practice fascinated me and instilled a desire to make the comparison between composition and teaching practices, one that is not often made. I would also become interested in reading as a form of professional development for contemporary teachers of English.

Encouraged by my major professor who fostered a space for dialogue during the semester, I began revisiting Woolf's late work during the summer prior to this academic year. My readings consisted mostly of supplementary scholarship on Woolf that I hadn't been exposed to previously, as well as contemporary teaching practices that I thought would be relevant for this particular project. I discovered that several articles at least

mentioned Woolf's relationship with the elite university she sought to dismantle. Several studies considered Woolf's lack of formal education, many argued that this enraged her, 
causing her to commit to a critique of elite patriarchal education and the status quo. I found scarce research linking Woolf's compositional practices with pedagogy. There were no papers considering Woolf pedagogically. Some of these limitations were addressed when I discovered the work of Melba Cuddy-Keane. Her text Virginia Woolf, the Intellectual and the Public Sphere helped situate me in the historical context Woolf was writing in. I placed particular emphasis on the 1930s and early 40s because the literature I was using came from that period. Cuddy-Keane's notion of the pedagogical Woolf truly informs this project and allowed me to synthesize Woolf's aesthetic projects and pedagogy. I used this text as a segway between literary criticism and educational scholarship; however, I had to constantly remind myself that there isn't a fluid passageway between literature and teaching practices. On the one hand, those two practices are complicated and cannot easily be sewn together. On the other hand, I think it is harmful or at least reductive to allow these two practices and professions to be completely separate. The introduction of national and global "standards" in elementary, secondary, and tertiary education during the $20^{\text {th }}$ and $21^{\text {st }}$ centuries has brought about a period of immense rigidity in teaching. This thesis is in part, an attempt to provide teachers more flexibility in what they choose to teach, how they choose to teach it, as well as choosing the supplementary material they will read in order to inform their practices. Like the teachers whose work I examine in the literature review, my purpose is to show how literature, here specifically Woolf's, could be used as a tool for increasing student autonomy and participation within existing school environments. When teaching standards are based upon essentialist or universal principles, teachers might not want to read in order to gain independence, they might not see the point in professional 
development if there is literally no room for development. I wanted this to make its appearance because this is truly where it belongs- bearing these realities in mind while writing is really an essential part of this project. I hope that it will also inspire my readers to open their mind to the possibility of an alternative pedagogy, one that can be adopted by individuals reflecting on different educative environments. Although many teachers and researchers use the term "pedagogy" with its strict contemporary signification as a teaching practice, the first appearance of the term was defined as a place of learning and not as a teaching practice. I hope to combine, through careful analysis, both the old and the new definition of this term. Pedagogy should vary depending on where the learning takes place. In order for this project to be successful, I had to carefully consider teaching practices and the environments in which this model may be used. Based on the literature review in Section 1, I propose that Woolf's model for reading and teaching can increase autonomy and self-reflexivity in contemporary classrooms for both students and teachers. I believe that Woolf tried to blur the lines between teacher/student, writer/reader. She wanted to collapse the distance between the teacher/writer and reader/student, allowing space for the student to gain agency and autonomy by responding to and collaborating with the teacher. Her approach would allow members of each social class to investigate their own ideas and collectively consider them with others. Woolf opposed the model of education that permitted an authority figure to lecture others based on their own opinion or "competence." She spent significant time dwelling on her own style and approach, as it was through her writing that she conveyed her ideas. Her incessant practice were recorded in her personal diary on March 4, 1936, "Well I'm almost through copying the raid scene, I shd. think for the $13^{\text {th }}$ time. Then it will go tomorrow, \& I shall have I think 
one day's full holiday_if I dare — before rereading ( $D V$ 14). This constant attention resembles the dedication a teacher must demonstrate in her lesson plans and syllabi. To make this argument, I found grounded theory useful as a methodological approach. Building upon texts from the University library and databases such as the MLA International Bibliography allowed me to collect pieces of past scholarship and synthesize them into a new model.

I searched in the texts that I was reading for passages that supported my views on Woolf's work. I had to search for sentences where Woolf explicitly sought her audience and interacted with them in dialogue that resembled teaching methods. Once I discovered these examples, I thought carefully about how they fit into this project and situated myself necessarily in the historical context she was writing in. Once I had a better understanding of what educational practices were like in the 1920s and 30s in England, I could begin to write about why and how Woolf's views might be applicable in the twenty-first century. I had to distinguish between that context she was writing in and educational environments now to produce a model that could be beneficial in classrooms today. Reading the work of humanities scholar and educator Gayatri Chakravorty Spivak, who has written extensively on the subject of humanities education, and having my own experience in several urban school programs, allowed me to create a foundation for teaching that I believe is timeless but requires the educator to spend generous amounts of time thinking about how they can increase the autonomy of their students and themselves. The study of daily rituals used by teachers is beyond the scope of this thesis. Instead of trying to provide several anecdotes and comparing Woolf's work with others, this project envisions the structure of school systems today and finds ways to shed light on a type of 
mindset that can be adopted within the structure of teacher's daily routines. I chose this method because I thought it would be reductive and also clumsy to lump together Woolf's thoughts with existing teaching practices. Instead, I am using Woolf's thoughts and composition as a model for contemporary educators to reflect on teaching. Teachers can grapple with, deconstruct, and adopt the model that Woolf creates as a foundation, and I believe that is exactly what Woolf sought for her readers.

It should be clear that this thesis is my interpretation of Woolf's own thoughts on teaching and reading practices. Bringing literature and educational scholarship together was the most challenging aspect of this project. Bridging this work across continents and historical periods, Woolf's work in the $20^{\text {th }}$ century with the role of educators in the $21^{\text {st }}$ is not a finite or simple feat. That is why I carefully constructed this model to serve the purpose of various educational environments. I didn't necessarily have a level of education in mind when I started this thesis; I was mostly interested in learning how Woolf's ideas could have an impact on the practice of teaching in general. The methods and findings should not be adopted as finite conclusions; instead, they should function as a guideline for educators who can use this maxim, as a vehicle for their own desired ends.

An essential part of the methodology for this thesis was the recognition that this project cannot be a panacea. Instead, this is a model that is contingent upon reflection and adaptability in different environments. This is why I place due emphasis on reading Woolf's theory as a model rather than providing tangible lesson plans that are already prepared for universal application. I didn't follow that type of objective thinking, nor would Woolf (I contend) recommend using an essentialist or universal approach. 


\subsection{RELEVANCE FOR TODAY}

Reading literature as an alternative practice for professional development is becoming more popular (Thompson). As I have shown, teachers have started to form groups for collective reading with their colleagues (Goldberg \& Pesko 40). Together, these groups select texts and carefully examine their own reading practices to understand how it might be useful for teaching their students tools for reading. The academic buzzword, aforementioned in this thesis that is used to describe this practice is metacognition. Teachers record a sense of clarity when they return to reading challenging fiction. They might read books that would challenge them so they experience something akin to what their students feel when they ask them to read challenging texts.

Some teachers will take this group activity and create units on collaborative group learning in their classroom. The purpose of my thesis is twofold. On the one hand, I want to encourage teachers to continue reading in groups and incorporating reflections into their classroom. On the other hand, I would like to push literary scholarship on scenes of reading further. By doing this, I hope that both practices will encourage more people to think about how reading can be effectively pedagogic. Here I use the example of Woolf's work because she was a writer immersed in thoughts about both aesthetics and education. Though "pedagogy" was not part of her vocabulary, Woolf encouraged active readers to form their own conclusions. Self-reflexivity was at the heart of Woolf's writing, and I believe that she hoped her readers would be self-reflexive as well. Reading Woolf could be an important part of new scholarship connecting teaching practices with critical reading. I hope that my research will excite literary scholars who have always noticed the 
pedagogical value of texts but repressed their thoughts because reading wasn't a popular form of professional development in the past.

More importantly, I am excited to engage with individuals who have never noticed the educational value of fiction. In the next few decades, teachers may use this model as a starting point, moving away from attending irrelevant conferences or only readings texts that offer lessons plans that are already made and standardized for any classroom. I hope educators will move away from the days of worksheets found online or instructional books, and push toward group learning models inspired by the teacher's experience during professional development. I emphasize reading in groups with colleagues and students as a preferred practice. Reading with others and forming one's own conclusions based on the environment one lives in and the text one reads, was a significant part of Woolf's argument. If studies demonstrate the effectiveness of teachers reading novels, then it should be appropriate to examine how reading Virginia Woolf's texts could be helpful for teachers who want to encourage their students to become self reflexive independent readers and thinkers (Goldeberg \& Pesko 40). 


\section{CHAPTER 4}

\section{FORGING AHEAD}

I would like to begin with a published approach for professional development and then I will turn towards creating my own model based on the findings in section 2 .

Kierstin H. Thompson suggests that teachers can benefit from the following practices:

1. Read a text that stretches you as a reader. One of the most influential opportunities I had as a young teacher was working with a much more knowledgeable colleague who asked me constantly about books I had read and if I would be willing to read others and discuss them. Because of these conversations, I read and discussed novels such as Dostoevsky's The Brothers Karamazov, Faulkner's Light in August, and Robinson's Housekeeping, all of which I eventually integrated into teaching units. But there were other novels... that we read, discussed, and agreed didn't have the right student appeal, were too abstract, or were incongruent with the aims of the course.

2. Invite colleagues to read a book with you. Another way I've been exposed to new texts is through literature classes not intended for teachers, ones that leave me thinking about instructional possibilities on my own. And although I get some recommendations for books at conferences, these events do not provide the sustained and ongoing reflection that enables me to actually incorporate the text into my classroom, especially if the text is a novel. When I have had colleagues agree to read a new book with me, it's helped to keep 
my passion and ambition in check. That is, through discussion we together try to determine if the book's content and pedagogical value is as great as I first thought when I read it on my own.

3. Ask to pilot a text. At the school where I teach, as with many schools, there is a formal process for proposing, piloting, and adopting a new text in course curriculums. I see the merit in such a review process, but I also know that to reach the point of text adoption teachers need more than documentation. They need support from colleagues to think in alternative ways about a text they might find intimidating...

Propose a professional development opportunity focused on literature. In my department, we get conflicting directives on whether we can talk about literature during our teacher institute days, and too often those conversations are only in the service of designing common assessments, writing learning targets, or aligning curriculum with standards. There are a handful of experiences I've had in my district over the last 15 years that offer as a vision for what professional development in literature might look like. For two department meetings, my former department chair provided time to discuss the novel The Good Thief as a way to engage in conversation about the quality of classroom texts and to judge whether this novel was dynamic enough for classroom conversation and written analysis. Another rather simple but enriching experience was one my first department chair created: an end-of-the-year department meeting devoted to just reading and discussing a short story or a poem. The goal here was not to determine the 
text's curricular value, but to engage department members as critical readers. Though this is an enjoyable experience for English teachers, it doesn't mean it's frivolous (42-3). I quote Thompson's work extensively because this is a teaching and learning model that I wish to build upon. If teachers with fifteen years of experience testify to the value of incorporating literature into professional development, then we can think of how teachers might use Woolf's work during these sessions. Although in the past decade, as Thompson suggests, incorporating literature has been frowned upon by some administrators, teachers who continue to publish work and show the value of this practice might be able to overcome these objections and develop pedagogical practices rooted in collective development. Thompson notes that successful programs require support. A recurring theme that I observed in Thompson's work is the notion that using literature for professional development is both challenging and enjoyable for teachers. The reason why reading literature in work environments has been frowned upon is a symptom of equating reading with pleasure and not critical inquiry (Goldberg \& Pesko 40). Goldberg and Pesko are advocates for incorporating pleasure reading into professional development. If teachers do not enjoy reading, then how will their students? Will teachers be expected to read in a monotonous tone or should they be excited about the material they share and engage with students in the classroom?

Goldberg and Pesko started a teacher's book club as a free and open resource for educators in the Midwest with any level of experience (41). The purpose of the club was 
to move away from an understanding of reading as a set of competencies to be mastered. Instead, the authors suggest that contemporary English teachers are gradually beginning to realize the importance of considering readers and the context where books are read, namely, how one's learning environment influences their interpretation of texts. They argue that,

Teachers require new ways of teaching, including such approaches as readers' workshops, literature circles, and book clubs to promote higher-order thinking, critical reading skills, and a positive attitude toward reading (39).

Educators will benefit from constantly educating themselves, and one way that they are able to do this, Goldberg and Pesko suggest, is by revisiting texts, making notes on the texts themselves, and subsequently thinking about their own reading of the text, a practice called metacognition. Rather than distancing themselves further from their students, teachers can share insight from their own readings of texts and learn more from student's perspectives on the text. The process is reciprocal rather than regurgitated, and that is the way Woolf preferred learning interactions. Beginning with Woolf's earlier work on education, we can use the models purported by Goldberg, Pesko, and Thompson. I recommend readers/teachers starting with The Common Reader(s) (1925-1932). From there, it would be important to turn to her treatment of education in A Room of One's Own (1929). Three Guineas (1938), "The Leaning Tower" (1940) and "How Should One Read a Book" (1932). These texts permit us to engage with Woolf's understanding of education as a war making institution during her lifetime, but also, it can help readers understand how her writing style is pedagogical. As teachers read these texts, I hope that they will help to shape active and critical thinkers: 
Do not dictate to your author, try to become him. Be his fellow-worker and accomplice. If you hang back and criticise at first, you are preventing yourself from getting the fullest possible value from what you read. But if you open your mind as widely as possible, then signs and hints of almost imperceptible fineness, from the twist and turn of the first sentences will bring you into the presence of a human being unlike any other. (259)

Having a full understanding of what one reads and how one reads will have a greater impact on how the teacher thinks about the material they teach. Goldberg, Pesko, and Thompson's articles support this argument because they see the value in teachers actually reading the texts that they teach and evaluating their own reading process so they can help their students form their own independent conclusions. Even practitioners who take the first step by attending book club meetings or professional development incorporating literature run the risk of imposing their own reading upon their students. This is where I will promote the two models I am working with, because both studies ignore this fact. It will be helpful for teachers to read Woolf's work specifically for professional development because of the democratic model of pedagogy she offers through her writing.

I want to offer a similar argument for my readers. My model should be read as a flexible and adoptable framework for various educational needs depending on environment. Also dependent on funding, support, participation, and leadership, I offer the following. In the tradition of Goldberg and Pesko's book club, I believe teachers would benefit from meeting with small groups of 10 to 20 educators. When they meet they could select which of Virginia Woolf's texts they will read. I recommend reading 
them in chronological order (listed earlier in this section). Especially for teachers, reading Woolf's development literally by placing her texts in conversation with one another is instructive. Though I have not read through all of her personal diaries that were published after her death, I believe that it would provide a fruitful supplement for teachers concerned with her major work. The diaries are organized according to date, which helps readers who can determine which one to supplement with the other texts they are reading by her at the same time period.

To initiate the book club, the teachers should receive flyers (a practice used by Goldberg and Pesko) inviting them to join the group. This is an inexpensive way compared to meeting for conferences, which often require funding for travel and admission. The book club should be a free and regular meeting. Each member should be told a week ahead of time what to read. If they do not have the financial ability to buy the text themselves, the department chair can call local libraries and see which ones they offer. When the teachers meet, the time should be completely devoted to discussion. Like the English seminar in higher education, they can read excerpts from texts to make crucial points, but they shouldn't be reading the book for the first time during the allocated time.

Each teacher should have the opportunity to speak about the following: (I) What was one take away from the book we read this week? (II) How did you read the book? Were there any practices you used that helped (highlighting, sticky notes, free writes)? (III) What are your thoughts on incorporating Woolf's ideas of excerpts from the text intro your class? Once each participant has a turn to speak and audience members have taken notes, they can split into small groups of two or three to discuss more specifically 
how they could use what they learned to help their students meet the designated literacy standards. They can complete the session by creating one exercise that they will actually use in their class during the academic year. These meetings can be held both during the academic year and the summer when teachers are on vacation. If teachers cannot attend a session due to their schedule, there is no obligation. If possible, another teacher might take notes during the allocated time and email the teachers who were absent.

If the technology is available and necessary, teachers may Skype in or use alternative modes of digital attendance. It wouldn't hurt to extend the invitation to parents who would benefit from learning more about how their child is being educated during the day, and how they can increase their child's literacy skills while they are home. Having family involvement might encourage parents to learn more about what their child is learning and develop respect for the effort teachers put into educating their child. Opposed to more costly models of professional development, the teacher's book club has been proven to help educators think about what it will take to reach their students, which texts will be appropriate and productive for their students, and how they can engage student's families. Using this outline of Woolf's work in Section 2 of this thesis and the research conducted on teachers' book clubs in the past can be useful for contemporary English teachers who are interested in alternative models for professional development. 


\section{CHAPTER 5}

\section{CONCLUDING REMARKS}

My findings support research on the use of literature for professional development. Following models created by Goldberg and Pesko in 2000, and Thompson in 2014, this

thesis argues that incorporating Woolf's late work into discussions among teachers about pedagogy and reading will improve their ability to reach their students and increase autonomy in the classroom. When teachers revisit their own reading practices, choosing challenging books for themselves and reading them thoroughly with colleagues, their teaching practice might begin to resemble this professional development.

Encouraging thinkers to form independent conclusions about texts (as Woolf did during her lifetime) allows students to grow as readers. In the face of increasing pressure upon teachers and students to meet state mandated literacy standards, this thesis turned toward Woolf as a model for encouraging reflective rather than rote thinking. I am hopeful that my project will inspire more educators to advocate for time allocated for reading literature with their colleagues. In discussion groups they can take what they learn and apply it to lesson plans or units throughout the academic year. On the other hand, I hope to encourage literary scholars to think about the practical use of scenes of reading for their own educative experiences. If even a small percent of teachers gradually begin to adopt a dialogic model of educating others as well as themselves, then this thesis will have been a success. This model is flexible and can be adopted section-by-section. I 
hope that teachers will take ideas that are applicable to their teaching environment and use them in a way that will be beneficial for their students and themselves alike. 


\section{BIBLIOGRAPHY}

Barber, Stephen M. "States of Emergency, States of Freedom: Woolf, History, and the Novel." Novel: A Forum on Fiction. 42.2. Duke University Press.

Web.

Butler, Judith. Frames of War. 2009. Michigan: The University of Michigan Press. Web.

Butler, Judith. Precarious Life: The Powers of Mourning and Violence. 2004. London: Verso. Web.

Cuddy-Keane, Melba. Virginia Woolf, the Intellectual, and the Public Sphere. 2003. Cambridge University Press. Print.

Einstein, Albert, Freud, Sigmund. Einstein on Peace. Montana: Literary Licensing LLC. 2001. Web.

Flint, Katie. "Reading Uncommonly: Virginia Woolf and the Practice of Reading." The Yearbook of English Studies. 26. 1996. Web.

Friedman, Susan Stanford. "Virginia Woolf”s Pedagogical Scenes of Reading: The Voyage Out, The Common Reader, and Her 'Common Readers'." Modern Fiction Studies 38.1. 1992. Web.

Gay, Peter. "On Not Psychoanalyzing Virginia Woolf.” The American Scholar 71.2. 2002. Web.

Goldberg, M. Shari, Pesko, Ellen. "The Teacher Book Club.” 2000. Education Leadership. 39-41. Web.

Lesjak, Carolyn. "Reading Dialectically.” Criticism. 55.1. Wayne State University 
Press. 2013. Web.

Hsieh, Lili. "The Other Side of the Picture: the Politics of Affect in Virginia Woolf's Three Guineas." Journal of Narrative Theory 36.1. Eastern Michigan University 2006. Web.

Nussbaum, Martha. "The Professor of Parody." 1999. New York: The New Republic. Web.

Russell, Richard R. "Radical Empathy in Virginia Woolf’s Mrs. Dalloway." Genre 48.3. University of Oklahoma Press. 2015. Web.

Said, Edward. Representations of the Intellectual. 1994. New York: Vintage Books. Web.

Spivak, Guyatri C. Other Asias. 2007. New Jersey: Wiley-Blackwell. Web. Thompson, H. Kierstin. "Beyond the Stacks: Why High School English Teachers Should Be Talking About Book.” 2014. English Journal. 103.6. 38-44. Web. Woolf, Virginia. A Room of One's Own. 1929. Ed. Mary Gordon. Orlando: Harcourt, Inc. 1983. Print.

Woolf, Virginia. Between The Acts. 1941. Orlando: Harcourt, Inc. 2008. Web. Woolf, Virginia. The Diary of Virginia Woolf, Vol. 4. 1931-35. Orlando: Harcourt, Inc. 1983. Print.

Woolf, Virginia. The Diary of Virginia Woolf, Vol. 5. 1936-41. Harcourt, Inc. 1985. Print.

Woolf, Virginia. “The Leaning Tower.” 1940. Ed. Stuart N. Clarke. 2000. London: Chatto \& Windus. Web.

Woolf, Virginia. The Years. 1937. Mariner Books. 2002. Web. 
Woolf, Virginia. "Thoughts On Peace in an Air Raid." 1940. New York: The New Republic. Web.

Woolf, Virginia. Three Guineas. 1938. Philadelphia: Harcourt, Inc. 1963. Web. 